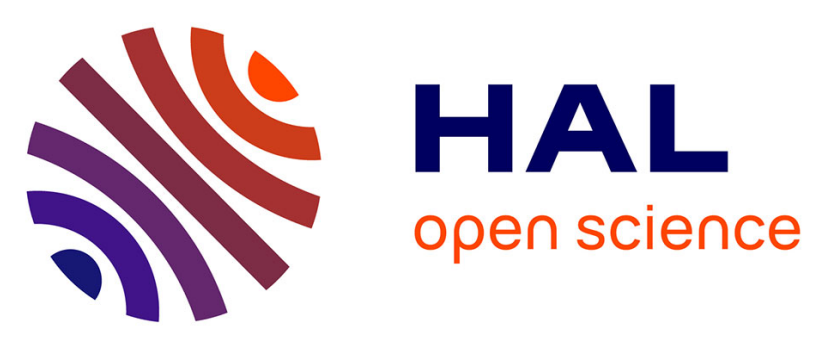

\title{
Finding of trout (Salmo cf. trutta) in the Northern Jordan Valley (Israel) at the end of the Pleistocene: Preliminary results
}

Aurélia Borvon, Anne Bridault, Rebecca Biton, Rivka Rabinovich, Marion Prevost, Hamudi Khalaily, François Valla

\section{To cite this version:}

Aurélia Borvon, Anne Bridault, Rebecca Biton, Rivka Rabinovich, Marion Prevost, et al.. Finding of trout (Salmo cf. trutta) in the Northern Jordan Valley (Israel) at the end of the Pleistocene: Preliminary results. Journal of Archaeological Science: Reports, 2018, 18 (18), pp.59-64. 10.1016/j.jasrep.2018.01.008 . halshs-01850067

\section{HAL Id: halshs-01850067 \\ https://shs.hal.science/halshs-01850067}

Submitted on 28 Oct 2019

HAL is a multi-disciplinary open access archive for the deposit and dissemination of scientific research documents, whether they are published or not. The documents may come from teaching and research institutions in France or abroad, or from public or private research centers.
L'archive ouverte pluridisciplinaire HAL, est destinée au dépôt et à la diffusion de documents scientifiques de niveau recherche, publiés ou non, émanant des établissements d'enseignement et de recherche français ou étrangers, des laboratoires publics ou privés. 


\title{
Finding of trout (Salmo cf. trutta) in the Northern Jordan Valley (Israel) at the end of the Pleistocene: Preliminary results
}

\author{
Aurélia Borvon $^{\mathrm{a}, \mathrm{b}, *}$, Anne Bridault ${ }^{\mathrm{a}}$, Rebecca Biton ${ }^{\mathrm{c}}$, Rivka Rabinovich ${ }^{\mathrm{c}}$, Marion Prevost $^{\mathrm{d}}$, \\ Hamudi Khalailye, François R. Valla ${ }^{\mathrm{a}}$ \\ ${ }^{\text {a }}$ CNRS, UMR 7041, Maison René Ginouvès, 92000 Nanterre, France \\ ${ }^{\mathrm{b}}$ Comparative Anatomy Lab, Nantes Atlantic College of Veterinary Medicine, Food Science and Engineering (ONIRIS), 44000 Nantes, France \\ ${ }^{\mathrm{c}}$ Institute of Archaeology, National Natural History Collections, the Hebrew University of Jerusalem, Jerusalem 91905, Israel \\ d Institute of Archaeology, the Hebrew University of Jerusalem, Jerusalem 91905, Israel \\ e Israel Antiquities Authority, P. O. B. 586, 91004 Jerusalem, Israel
}

\section{A R T I C L E I N F O}

\author{
Keywords: \\ Salmonidae \\ Trout \\ Eynan/Ain Mallaha \\ Hula Basin \\ Southern Levant \\ Final Natufian
}

\begin{abstract}
A B S T R A C T
Tens of thousands of fish bones were recovered from the Final Natufian (Late Epipaleolithic) layer of the site of Eynan/Ain Mallaha (Northern Israel) dated to the end of the Pleistocene. Almost a hundred of them were attributed to a Salmoninae, most probably a trout Salmo cf. trutta. This is the southernmost attestation of a Salmo species in the Near East, past and present. It is suggested that trout were present locally as small populations at least at the end of the Pleistocene.
\end{abstract}

\section{Introduction}

The mid-1960s witnessed a growing awareness of the widespread importance of fish for the diet of late prehistoric societies. This trend was fuelled by influential publications such as those by Lee (1979) and Binford (1968). Lee underlined that, according to ethnographic records, fish are often the main food resource in temperate latitudes (Lee, 1979: 42) while Binford suggested a stress model where: "increased dependence on aquatic resources during the terminal and immediately postPleistocene period" was supposed to induce an increase in sedentism, population growth, food storage and finally grain agriculture (Binford, 1968: 332-333). Thus, an intellectual stimulus was set down to prompt studies of archaeological fish remains while, on the other hand, simultaneous improvement in field recovery techniques through generalised sieving favoured the collection of representative samples. Nonetheless, the analysis of fish bones was hampered by lack of good reference collections needed for identification.

The first samples of fish remains from Natufian (Late Epipaleolithic) deposits were published a few years later. They originated from sites in different settings (Fig. 1): Hatoula, in the western foothills of the Judean hills (Lernau, 1985; Lernau and Lernau, 1991), el-Wad Terrace, in the foothills of Mount Carmel (Valla et al., 1986) and Eynan/Ain Mallaha (Late Natufian occupations), in the Hula Basin (Desse, 1987).
The finding of rare sea fish remains at Hatoula was of peculiar interest because it implied transport over a distance of about $30 \mathrm{~km}$. At el-Wad and Eynan/Ain Mallaha, fish were from the local environment.

The nature and possible intensification of fishing by the Natufians are yet to be fully understood (Bar-Yosef and Zohar, 2010). Besides the relative importance of fish as a food supply, other issues became apparent such as local versus distant captures as well as the environmental significance of the finds. For example, the recovery of fish bones at Hilazon Tachtit (Cyprinidae and Mugilidae families), in western Galilee (Bar-Yosef and Zohar, 2010), and at Baaz Rockshelter (Cyprinidae and Salmonidae) in Syria, today in desert conditions (Conard et al., 2013; Napierala et al., 2013), opens the possibility either of the presence of suitable waterbodies in the vicinity of the sites or relatively distant captures. Finding of specimens assigned to the Salmo genus in the Final Natufian layer at Eynan/Ain Mallaha brings further elements to the discussion of these questions.

\section{Material and methods}

Renewed excavations at Eynan/Ain Mallaha (1996-2005) by F. R. Valla and H. Khalaily (Valla et al., 2007, 2017) produced tens of thousands of fish bones from the Final Natufian layer dated between 10,730 and $9760 \mathrm{cal}$ BC, $2 \sigma$ (Intcal13; Reimer et al., 2013) (Table 1).

\footnotetext{
* Corresponding author at: Maison de l'Archéologie de l'Ethnologie, UMR 7041 ArScAn Équipe Archéologies environnementales, 21 allée de l'Université, 92000 Nanterre, France.

E-mail addresses: aurelia.borvon@mae.u-paris10.fr (A. Borvon), anne.bridault@mae.u-paris10.fr (A. Bridault), rebecca.biton@mail.huji.ac.il (R. Biton),

rivkar@mail.huji.ac.il (R. Rabinovich), marion.prevost@mail.huji.ac.il (M. Prevost), hamudi@israntique.org.il (H. Khalaily), francois.valla@wanadoo.fr (F.R.Valla).
} 


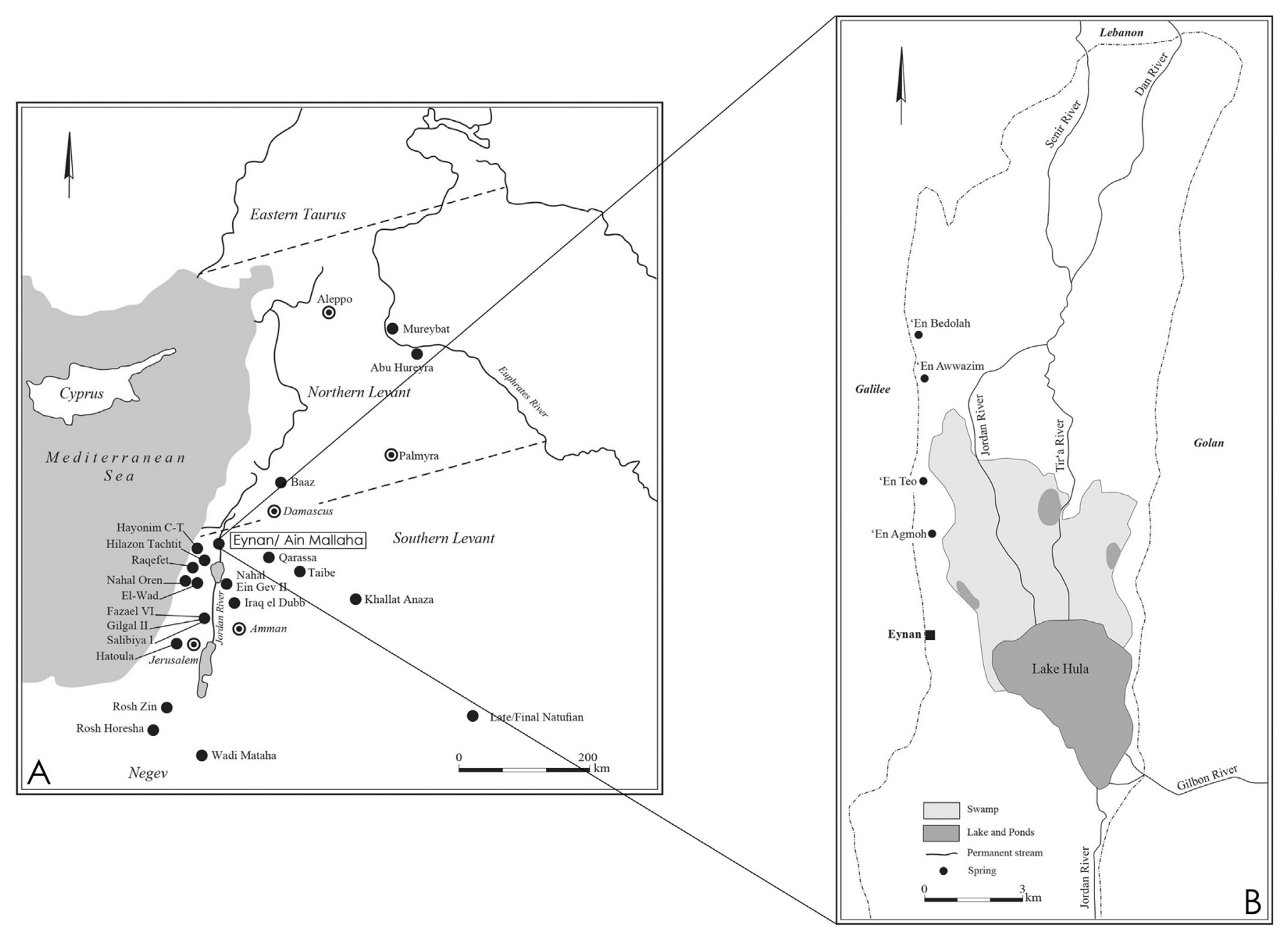

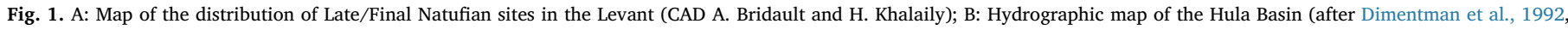
modified, CAD H. Khalaily).

Table 1

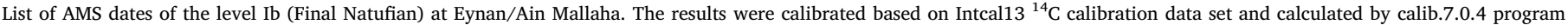
(Reimer et al., 2013).

\begin{tabular}{|c|c|c|c|c|c|c|}
\hline Ref. samples & level/struct & ref Lab. & Age BP & sd & cal BC $1 \sigma$ (IntCal13) & cal BC $2 \sigma($ IntCal13) \\
\hline EM05 K95b, 1031-2 & $\mathrm{Ib} /$ st 230 & GifA 70,013 & 10,200 & 50 & $10,061-9858$ & $10,157-9760$ \\
\hline EM97 R97 6165 & Ib2/st 215 & GifA 99,332 & 10,530 & 100 & $10,705-10,433 ; 10,319-10,294$ & $10,742-10,170$ \\
\hline \multirow[t]{2}{*}{ EM99 R98c 7657} & Ib2/st 228 & GifA 100,400 & 10,540 & 90 & $10,696-10,448$ & $10,743-10,272 ; 10,268-10,196$ \\
\hline & Average Ib2 & & & & $10,639-10,460$ & $10,732-10,285$ \\
\hline
\end{tabular}

The site, in the Hula Basin of the Upper Jordan Valley, is known for its rich Natufian deposits which span most of the duration of this cultural entity (Ashkenazi, 2013; Bouchud, 1987; Bridault et al., 2008; Perrot, 1960, 1966, 1968; Weissbrod et al., 2017). In the recent excavations, the Final Natufian occupation is circa $50 \mathrm{~cm}$ thick, over a surface of about $120 \mathrm{~m}^{2}$ and includes five distinctive stone constructions distributed into two temporally separated building phases (Valla et al., 2007, 2017). A large fireplace from the basal building phase, structure 228 (Fig. 2), dated to 10,740-10,200 cal BC, $2 \sigma$ (Valladas and Kaltneker in Valla et al., 2007) (Table 1), was chosen for a pilot study of the fish, due to the abundance of remains in its fill (Valla et al., 2013).

During excavations, systematic wet sieving on 1-2 mm meshes was carried out to collect the fine fraction of the archaeological material. A thorough sorting of the fish remains from fireplace 228 was done by the first author under a stereomicroscope $(10-40 \times)$, guaranteeing exhaustive recovery of the material. Identification was carried out mainly using reference collections: National Natural History Collections (Hebrew University of Jerusalem, Israel), Dr. I. Zohar's personal collection, and Comparative Anatomy Lab collections of OnIRIs (Nantes Atlantic College of Veterinary Medicine, Food Science and Engineering, France).

\section{Results}

\subsection{Taxonomic composition of the studied sample}

Only a part of the fish bones from structure 228 has been studied to date. Already 7475 remains have been analysed and many more are expected to undergo analysis. Out of the analysed sample, 3471 were identified, at least to the family level (Table 2). Most of them were assigned to Cichlidae (Number of Identified Specimens, NISP: 2292) and to Cyprinidae (NISP: 1173). Head bones (mainly from the 


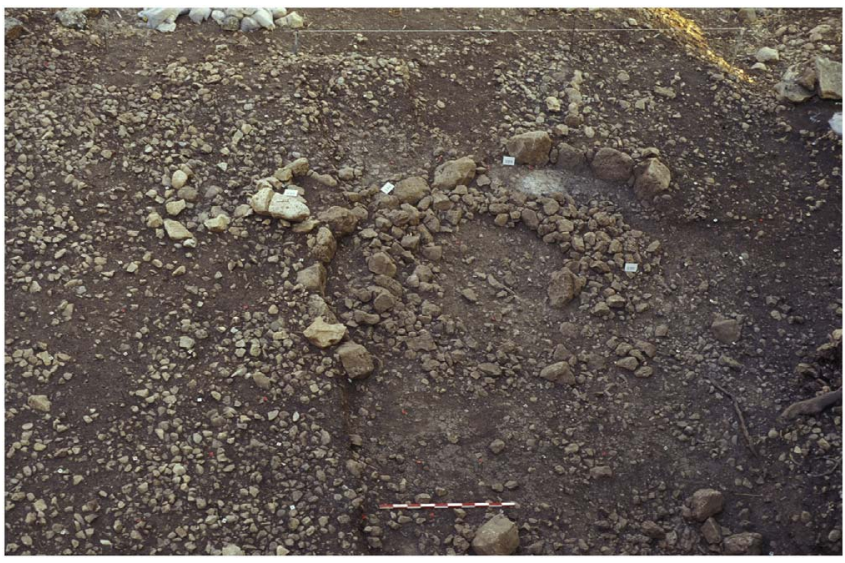

Fig. 2. General view of fireplace 228 in wall 225. Photo F. Valla.

Table 2

Taxonomic composition of the studied sample from structure 228 (Number of Identified Specimens - NISP)

\begin{tabular}{llll}
\hline Structure 228 & NISP & $\%$ NISP & $\%$ \\
\hline Cyprinidae & 1173 & 33.8 & \\
Cichlidae & 2292 & 66.0 & \\
Salmoninae & 6 & 0.17 & 46.4 \\
Identified & 3471 & 100 & 53.6 \\
Unidentified & 4004 & & 100 \\
Total & 7475 & & \\
\hline
\end{tabular}

splanchnocranium) and vertebrae of both taxa were recovered. Among the Cichlids, lower pharyngeal bone morphology demonstrates the presence of Coptodon zilli. The Cyprinidae family is more diverse with four species identified through their pharyngeal bones: Luciobarbus longiceps, Capoeta damascina, Garra rufa and the endemic extinct fish Mirogrex hulensis, out of the eight species known from Lake Hula (Zohar et al., 2014).

The most surprising find was that of six vertebrae exhibiting the lateral alveolar pattern characteristic of the Salmoninae sub-family, which includes Atlantic salmon Salmo salar and trout Salmo trutta complex (Fig. 3), since no representative of this sub-family is nowadays naturally present in the Near East. A scan of the material retrieved from other sectors of the site yield an additional 91 Salmo vertebrae, and more are expected. The 97 Salmo vertebrae so far identified form the largest record of this taxon in the prehistoric Levant. They nonetheless represent only a small fraction of the total number of fish remains at the site: in structure 228 , Salmo sp. accounts for only $0.17 \%$ of the NISP sampled so far.

The sample of Salmo vertebrae consists of 41 thoracic (or precaudal) vertebrae and 50 caudal vertebrae based on the presence or absence of haemal spines, as well as 6 unidentified vertebrae (Table 3).

\subsection{The Salmo sub-sample}

The Salmonidae are distributed throughout the Holarctic region (Bruslé and Quignard, 2013; Sanford, 2000). This family includes three sub-families, Salmoninae, Coregoninae and Thymallinae, easily identified based on vertebrae morphology (e.g. Le Gall, 1984). Within the Salmoninae, the distinction between Atlantic salmon Salmo salar and brown trout Salmo trutta is more difficult since both species are osteologically very close, with a high intra-specific variability (Desse-Berset, 1994; Guillaud, 2014; Guillaud et al., 2016; Le Gall, 1984). In order to try and differentiate between both species, we used X-ray pictures of the caudal vertebrae as recommended by Desse and Desse (1976) and Desse-Berset (1994). For the brown trout, the vertebral centrum shows a straight " $X$ " pattern, whereas for the Atlantic salmon, it is in the shape
A

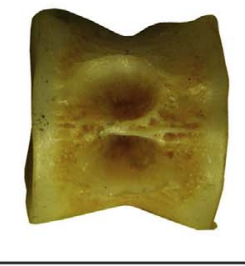

C

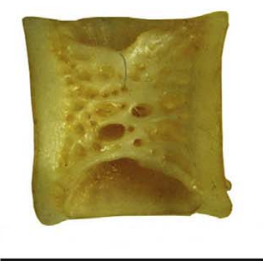

$\mathrm{E}$

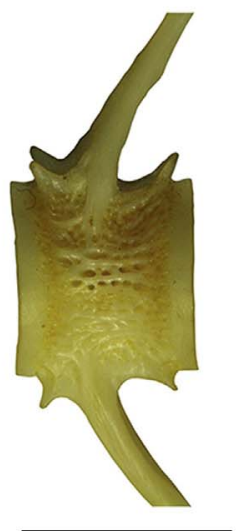

B


F

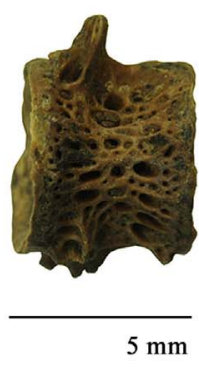

Fig. 3. Thoracic (dorsal and lateral view) and caudal vertebrae (lateral view) of A, C, E: Salmo trutta from the reference collection of the Comparative Anatomy Lab (ONIRIs), and for B, D, F: Salmo cf. trutta from Eynan/Ain Mallaha (thoracic vertebrae: EM96, H94c, 5576; caudal vertebrae: EM97, R97, 5843). The lateral alveolar pattern characteristic of the family is highly variable inside the different trout forms. Photos: A. Borvon.

Table 3

Distribution of the Salmo vertebrae in the Final Natufian level at Eynan/Ain Mallaha.

\begin{tabular}{llll}
\hline Salmoninae & St. 228 & outside St. 228 & Total \\
\hline Thoracic vertebrae & 1 & 40 & 41 \\
Caudal vertebrae & 5 & 45 & 50 \\
Vertebrae of indeterminate rank & & 6 & 6 \\
Total & 6 & 91 & 97 \\
\hline
\end{tabular}

of two opposite curved "Y"s (Fig. 4). Eight caudal vertebrae from Eynan/Ain Mallaha were successfully radiographed, and it is clear that their pattern is closer to trout than to salmon (Fig. 4).

\section{Discussion and conclusion}

Almost 7500 fish remains were studied from a sample originating from structure 228, Final Natufian Eynan/Ain Mallaha. This is the largest sample for the Natufian period for which available publications describe rarely more than a hundred items and usually even no more than a few dozen (Bar-Yosef and Zohar, 2010; Grosman et al., 2016; Van Neer et al., 2005). Cyprinidae and Cichlidae were expected in the context of Eynan/Ain Mallaha and they had already been previously reported (Desse, 1987, Zohar in Valla et al., 2007: 307). 


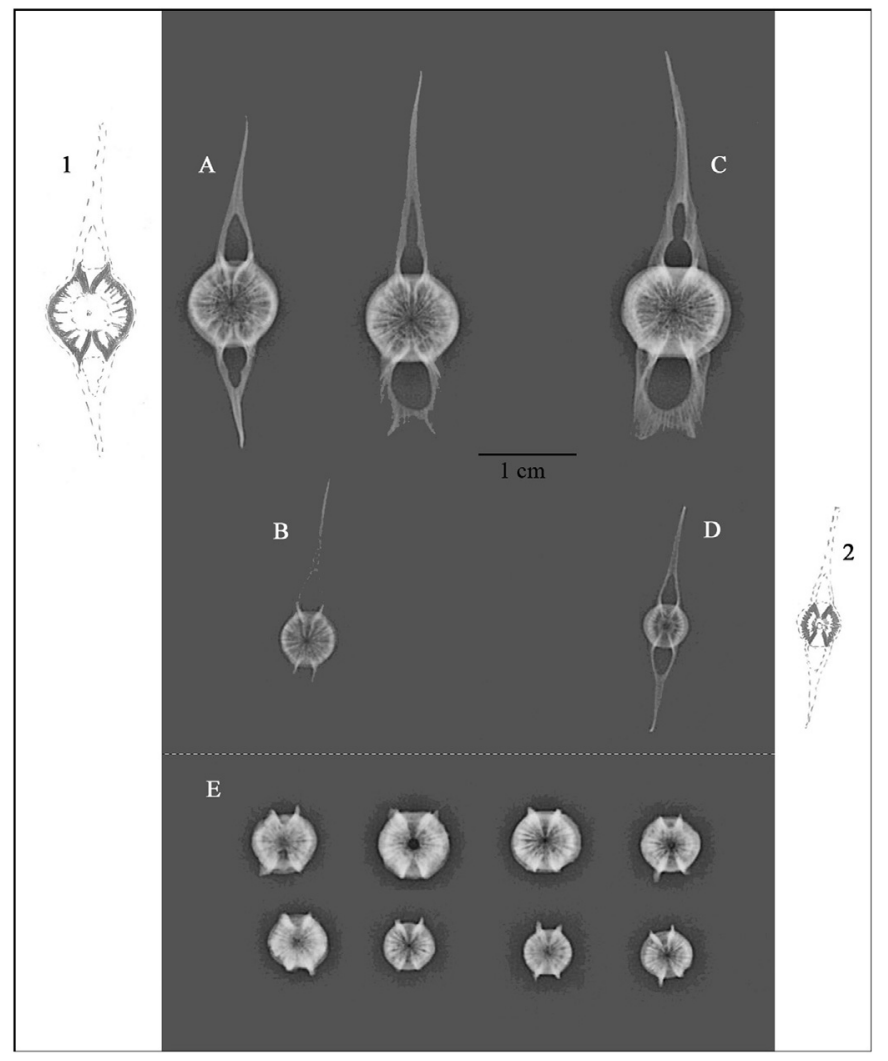

Fig. 4. Caudal vertebrae X-ray (X-ray picture: OnIRIs, Nantes, France) of A, B: Salmon Salmo salar, C, D: Trout $S$. trutta from the reference collection of the Comparative Anatomy Lab (ONIRIs), E: Salmo cf. trutta from Eynan/Ain Mallaha (from right to left and from top to bottom: EM97, O98d, 5834; EM96, O81, 5178; EM97, Q98, 6105; EM98, S95, 6502; EM97, P97, 5989; EM97, O98b, 6250; EM98, S95d, 7018; EM97, O99, 6251). Salmo caudal vertebrae drawing, after the X-ray picture, 1: Atlantic salmon S. salar, 2: Brown trout $S$. trutta.

\subsection{Anthropogenic origin of the Salmo bones}

The fish bones at the site were widely scattered and found mixed with the rest of the archaeofaunal remains - mostly food waste, suggesting that fish were part of the diet of the Natufian people. This is reinforced by the finding of a few possible fishing implements, mainly hooks and net weights at the site (Le Dosseur in Valla et al., 2004, Valla et al., 1998). No cut marks have been noted on Salmo vertebrae so far, but they are not expected on small-sized fish remains (Wheeler and Jones, 2009; Willis et al., 2008) and burning was observed on five Salmo vertebrae. Nonetheless, this may not reflect cooking activities, as bone can be unintentionally burnt when discarded at or near a fireplace (Asmussen, 2009).

No evidence of digestion, which could have raised the question of consumption by predator species, was noted (Jones, 1984, 1986; Nicholson, 1993, 2000). The fact that only vertebrae were recovered is probably related to the fragility of the head skeleton in the Salmoninae group, as it is seldom recovered from archaeological deposits (Butler and Chatters, 1994; Lubinski, 1996; Morales and Rosello, 1998). All in all, trout were apparently very unusual in people's meals.

\subsection{Which Salmo species?}

In addition to the osteological criteria, the attribution of the vertebrae to the Atlantic salmon can probably be excluded when considering its indigenous range: mainly in the northern Atlantic Ocean (Klemetsen et al., 2003; Porcher and Baglinière, 2011) (Fig. 5). It has been suggested, on the basis of archaeological finds, that salmon populations were resident in the western Mediterranean Sea from the Last
Glacial Maximum (21 ka cal BP) to the early Holocene (Guillaud, 2014; Kettle et al., 2008, 2011; Le Gall, 2008, 2010). To date, this is an open issue (Guillaud et al., 2016).

At Eynan/Ain Mallaha, a member of the trout group is a more likely candidate when considering their geographical distribution (Fig. 5). In the Near East, trout is recorded in the Upper Euphrates and Tigris Basins of southern Turkey (Baglinière, 1991; Bruslé and Quignard, 2013; Ombredane et al., 2011).

According to DNA studies, most European trout seem to belong to a dominant species, Salmo trutta. This species is constituted of an aggregate of interbreeding forms, each centred on a particular geographical setting but with considerable overlap (Bernatchez, 2001; Cortey et al., 2004, 2009; Ombredane et al., 2011). A few forms, very located, are still given a status of species, like Salmo platycephalus in southern Turkey and Salmo tigridis in the Tigris Basin, for the Near Eastern morphotypes (Sušnik et al., 2004, 2006; Turan et al., 2011). However no osteological criteria are available to differentiate them from the brown trout.

\subsection{Ecology}

As it is highly adaptable, Salmo trutta is a ubiquitous species that can be found in seas, lakes and rivers (Ombredane et al., 2011). However, sea trout are a migratory variety, whereas lake and river trout do not tolerate salt water. Their distribution is also limited by some physical parameters, mainly water temperature and oxygenation.

Trout favour well oxygenated water between $0^{\circ}$ and $20^{\circ} \mathrm{C}$, with optimal temperatures between $5^{\circ}$ and $17^{\circ} \mathrm{C}$, but they do not survive water above $22^{\circ}-26^{\circ} \mathrm{C}$ (Bruslé and Quignard, 2013; Elliott, 1982; Jonsson and Jonsson, 2009; Ombredane et al., 2011). In reproduction areas, water should not exceed $10{ }^{\circ} \mathrm{C}$. Thus, in rivers, spawning places are usually upstream.

\subsection{Did physical conditions in the vicinity of Eynan/Ain Mallaha 12,000 years ago match these requirements?}

To this day, the Hula depression is rich in fresh water (Fig. 1B). Many springs flow into its margins at the foot of the Galilee and Golan Heights, permanent streams run from the Anti-Lebanon Mountains, and the remnants of the lake occupy its lowest place. In recent past, the spring of Ain Mallaha presented a stenothermic temperature of 21-22 ${ }^{\circ} \mathrm{C}$ (Dimentman et al., 1992: 89). The Lake Hula was 3 to $4 \mathrm{~m}$ deep, with temperatures varying according to time of the day and seasons between $5^{\circ}$ and $37^{\circ} \mathrm{C}$. Its oxygenation was poorly documented (Dimentman et al., 1992: 19, 26-31). Its catchment extended north in adjacent mountains including Mount Hermon (Dimentman et al., 1992: 23). In such areas, as well as in the nearby upper Galilee, trout could have found suitable habitats even under modern conditions (Gruvel, 1931). This is also confirmed by the modern breeding of the rainbow trout Oncorhynchus mykiss, in such streams as Dan River (Fig. 1B) with temperatures today of $15^{\circ} \mathrm{C}$ all year round (Golani comm. pers. 2016).

The situation in the area during the Final Natufian can be reconstructed through archaeofaunal and palaeobotanical analyses. Some studies have pointed out the relative stability of environment (Ashkenazi, 2013; Biton et al., 2016), while other support a somewhat cooler climate in comparison to nowadays (Bar-Matthews et al., 1997, 1999, Hartman et al., 2016, Mienis in Valla et al., 2007). Generally speaking, as Tchernov (1997: 221) emphasised: "no real dry periods existed during the Late Pleistocene in the Southern Levant but [...] during this period the Southern Asian arid belt was always much wetter supporting a rich diversity of Palearctic species [...]". In the Hula, the wide variety of taxa recovered in layer Ib at Eynan/Ain Mallaha supports this view. Accordingly, even if it is doubtful that trout found optimal conditions in the immediate vicinity of the site, it is likely that they could live locally, at least in nearby hilly areas. 


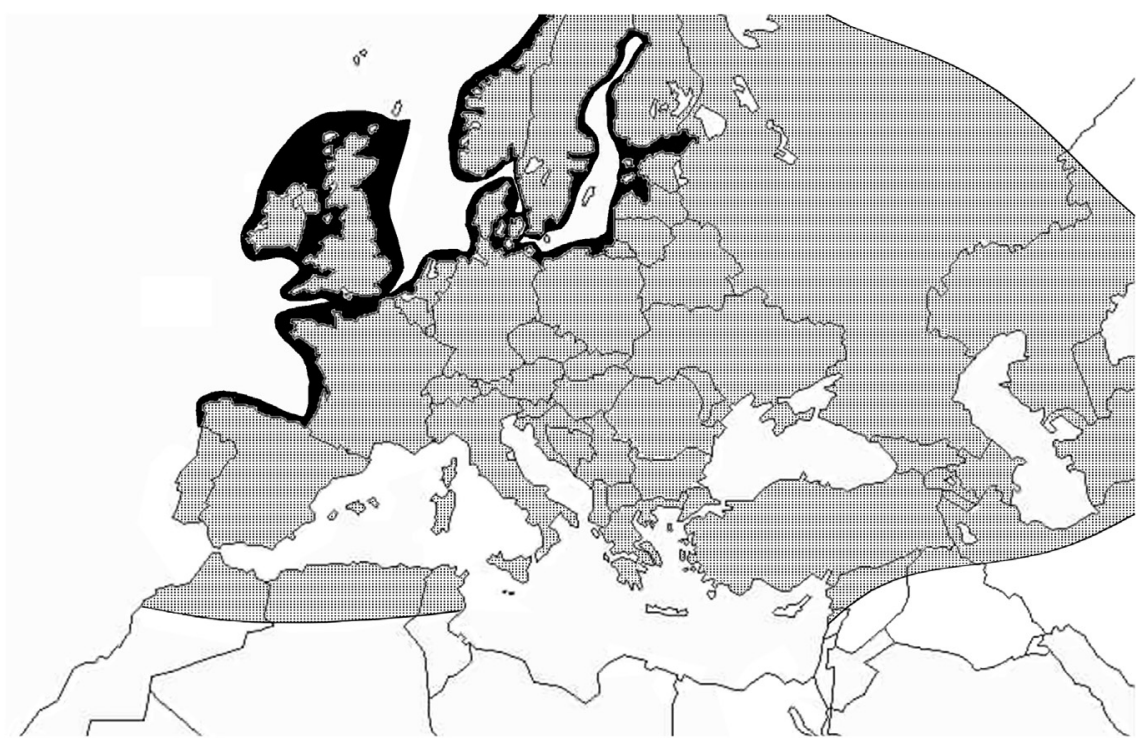

Fig. 5. Current spatial distribution of Atlantic salmon Salmo salar in black and brown trout Salmo trutta complex in grey (map after Baglinière, 1991, Bernatchez, 2001, Porcher and Baglinière, 2011, modified, CAD C. Picard). (For interpretation of the references to colour in this figure legend, the reader is referred to the web version of this article.)

\subsection{Conclusion}

All in all, it is likely that trout could have lived in the vicinity of Eynan/Ain Mallaha at the end of the Pleistocene. An alternative possibility, namely introduction by transport from further north, cannot be totally excluded in a context where trade of Cappadocian obsidian is well attested (Khalaily and Valla, 2013). Nevertheless, the most parsimonious hypothesis is their local presence, at least in the cooler rivers flowing into the Hula Valley from the north.

\section{Acknowledgements}

Excavations at Eynan/Ain Mallaha were sponsored by the Ministère des Affaires Etrangères (Paris) with help from the CARE Archaeological Foundation, the Wenner-Gren Foundation and the National Geographic Foundation. The CARE Archaeological Foundation and the Centre de Recherche Français à Jérusalem supported the work of Aurélia Borvon in Israel. The authors acknowledge the help of Dr. Irit Zohar (Oranim Academic College, Israel) in identifying the Lake Hula fish, by making her private osteological collection available from 2015 to 2016, and the constant support of Dr. Dani Golani (National Natural Collections, the Hebrew University of Jerusalem, Israel). Dr. Patrick Berrebi (CNRS, UMR 5554, France) provided information on recent studies in trout genetics. Catherine Picard (ONIRIs, France) is thanked for formatting certain figures. The authors are grateful to Christian Raphaël and Stéphane Madec (ONIRIs, France) for taking X-rays, to Ian Nicholson (OnIRIs, France) and Gali Beiner (the Hebrew University of Jerusalem, Israel) for English corrections to the manuscript.

\section{References}

Ashkenazi, S., 2013. Reconstruction of the habitats in the ecosystem of the final Natufian site of Ain Mallaha (Eynan). In: Bar-Yosef, O., Valla, F.R. (Eds.), Natufian Foragers in the Levant. Ann Arbor, International Monographs in Prehistory, International Series 19 Oxford, pp. 312-318.

Asmussen, B., 2009. Intentional or incidental thermal modification? Analysing site occupation via burned bone. J. Archaeol. Sci. 36, 528-536.

Baglinière, J.-L., 1991. La truite commune (Salmo trutta L.), son origine, son aire de répartition, ses intérêts économiques et scientifiques. In: Baglinière, J.-L., Maisse, G. (Eds.), La truite, biologie et écologie. INRA, Paris, pp. 11-22.

Bar-Matthews, M., Ayalon, A., Kaufman, A., 1997. Late Quaternary paleoclimate in the eastern Mediterranean region from stable isotope analysis of speleothems at Soreq cave, Israel. Quat. Res. 47, 155-168.

Bar-Matthews, M., Ayalon, A., Kaufman, A., Wasserburg, G.J., 1999. The eastern Mediterranean paleoclimate as a reflection of regional events, Soreq Cave, Israel. Earth Planet. Sci. Lett. 166, 85-95.

Bar-Yosef, D.E., Zohar, I., 2010. The role of aquatic resources in the Natufian culture. In: Eurasian Prehistory. 7. pp. 29-43.
Bernatchez, L., 2001. The evolutionary history of brown trout (Salmo trutta L.) inferred from phylogeographic, nested clade, and mismatch analyses of mitochondrial DNA variation. Evolution 55, 351-379.

Binford, L.R., 1968. Post-Pleistocene adaptations. In: Binford, S.R., Binford, L.R. (Eds.), New Persectives in Archaeology. Aldine, Chicago, pp. 313-341.

Biton, R., Boistel, R., Rabinovich, R., Gafny, S., Brumfeld, V., Bailon, S., 2016. Osteological observations on the Alytid Anura Latonia nigriventer with comments on functional morphology, biogeography and evolution history. J. Morphol. 277, 1131-1145.

Bouchud, J. (Ed.), 1987. La Faune du Gisement Natoufien de Mallaha (Eynan) Israël. Association Paléorient, Paris.

Bridault, A., Rabinovich, R., Simmons, T., 2008. Human activities, site location and taphonomic process: a relevant combination for understanding the fauna of Eynan (Ain Mallaha), level Ib (final Natufian, Israel). In: Vila, E., Gourichon, L., Choyke, A. Buitenhuis, H. (Eds.), Proceedings of the 8th International Meeting of the ASWA (Archaeozoology of Southwestern Asia), Lyon 2006. Maison de l'Orient et de la Méditerranée (Travaux de la Maison de l'Orient, n49), Lyon, pp. 99-118.

Bruslé, J., Quignard, J.-P., 2013. Biologie des poissons d'eau douce européens. In: Seconde édition, Lavoisier, Tec et Doc, Paris.

Butler, V.L., Chatters, J.C., 1994. The role of bone density in structuring prehistoric Salmon bone assemblages. J. Archaeol. Sci. 21, 413-424.

Conard, N.J., Bretzke, K., Deekers, K., Masri, M., Napierala, H., Riehle, S., Stahlsehmidt, M., Kandel, A.W., 2013. Natufian lifeways in the eastern foothills of the anti-Lebanon mountains. In: Bar-Yosef, O., Valla, F.R. (Eds.), Natufian Foragers in the Levant. Ann Arbor. International Monographs in Prehistory, International Series. 19. pp. 1-16.

Cortey, M., Pla, C., Garcia-Marin, J.-L., 2004. Historical biogeography of Mediterranean trout. Mol. Phylogenet. Evol. 33, 831-844.

Cortey, M., Vera, M., Pla, C., Garcia-Marin, J.-L., 2009. Northern and southern expansions of Atlantic brown trout (Salmo trutta) populations during the Pleistocene. Biol. J. Linn. Soc. 97, 904-917.

Desse, J., 1987. Mallaha: l'ichthyofaune. In: Bouchud, J. (Ed.), La Faune du Gisement Natoufien de Mallaha (Eynan) Israël. Association Paléorient, Paris, pp. 151-156.

Desse, J., Desse, G., 1976. Diagnostic des pièces vertébrales des Chondrichthyens et des Téléostéens, vol. III: Téléostéens d'eau douce. L'expansion scientifique, Paris.

Desse-Berset, N., 1994. Les Poissons. In: Gallia Préhist. 36. pp. 219-224.

Dimentman, C., Bromley, H.J., Por, F.D., 1992. Lake Hula, Reconstruction of the Fauna and Hydrobiology of a Lost Lake. The Academy of Sciences and Humanities, Jerusalem.

Elliott, J.M., 1982. The effects of temperature and ration size on the growth and energetics of salmonids in captivity. Comp. Biochem. Physiol. B 73, 81-91.

Grosman, L., Munro, N.D., Abadi, I., Boaretto, E., Shaham, D., Belfer-Cohen, A., Bar-Yosef, O., 2016. Nahal Ein Gev II, a Late Natufian Community at the sea of galilee. PLoS One 11 (1), e0146647. http://dx.doi.org/10.1371/journal.phone.0146647.

Gruvel, A., 1931. Les états de Syrie. Richesses marines et fluviales. In: Exploitation ac tuelle, avenir. Société d'Editions Géographiques, Maritimes et Coloniales, Paris.

Guillaud, E., 2014. Étude archéo-ichtyofaunique des sites magdaléniens du Taillis des Coteaux et de La Piscine (Vallée de la Gartempe, Vienne). Taphonomie, biodiversité et techniques de pêche. Muséum d'Histoire Naturelle, Paris.

Guillaud, E., Cornette, R., Béarez, P., 2016. Is vertebral form a valid species-specific indicator for salmonids? The discrimination rate of trout and Atlantic salmon from archaeological to modern times. J. Archaeol. Sci. 65, 84-92.

Hartman, G., Bar-Yosef, O., Brittingham, A., Grosman, L., Munro, N.D., 2016. Hunted gazelles evidenced cooling but not drying during the Younger Dryas in the Southern Levant. PNAS 113 (15), 3997-4002.

Jones, A.K.G., 1984. Some effects of the mammalian digestive system on fish bones. In: Desse-Berset, N. (Ed.), $2^{\text {èmes }}$ rencontres d'archéo-ichthyologie, octobre 1983, Sophia Antipolis - Valbonne. CNRS, Paris, pp. 61-65. 
Jones, A.K.G., 1986. Fish bone survival in the digestive systems of the pig, dog and man: some experiments. In: Brinkhuizen, D.C., Clason, A.T. (Eds.), Fish and Archaeology. Studies in Osteometry, Taphonomy, Seasonality and Fishing Methods. BAR International Series, Oxford, pp. 53-61.

Jonsson, B., Jonsson, N., 2009. A review of the likely effects of climate change on anadromous Atlantic salmon Salmo salar and brown trout Salmo trutta, with particular reference to water temperature and flow. J. Fish Biol. 75, 2381-2447.

Kettle, A.J., Heinrich, D., Barett, J.H., Benecke, N., Locker, A., 2008. Past distributions of the European freshwater eel from archaeological and paleontological evidence. Quat. Sci. Rev. 27, 1309-1334.

Kettle, A.J., Morales, A., Rosello, E., Heinrich, D., Vollestad, L.A., 2011. Refugia of marine fish in the northeast Atlantic during the last glacial maximum: concordant assessment from archaeozoology and palaeotemperature reconstructions. Clim. Past 7, 181-201.

Khalaily, H., Valla, F.R., 2013. Obsidian in Natufian Context: The Case of Eynan (Ain Mallaha), Israel. In: Bar-Yosef, O., Valla, F.R. (Eds.), Natufian Foragers in the Levant. Ann Arbor, International Monographs in Prehistory, International Series. Vol. 19. pp. 193-202.

Klemetsen, A., Amundsen, P.-A., Dempson, J.B., Jonsson, B., Jonsson, N., O'Connell, M.F., Mortensen, E., 2003. Atlantic salmon Salmo salar L., brown trout Salmo trutta L. and Arctic charr Salvelinus alpinus (L.): a review of aspects of their life histories. Ecol. Freshw. Fish 12, 1-59.

Le Gall, O., 1984. L'Ichtyofaune d'eau douce dans les sites préhistoriques. In: Ostéologie, Paléoécologie, Paléethnologie. CNRS, Paris.

Le Gall, O., 2008. Les poissons des eaux douces pléistocènes sont-ils des indicateurs paléoclimatiques? Une approche élargie à l'Europe. In: Béarez, P., Grouard, S., Clavel, B. (Eds.), Archéologie du poisson. 30 ans d'archéo-ichtyologie au CNRS. Hommage aux travaux de Jean Desse et Nathalie Desse-Berset. Actes des XXVII rencontres internationales d'archéologie et d'histoire d'Antibes - XIVth ICAZ fish remains working group meeting, octobre 2007. APDCA, Antibes, pp. 311-326.

Le Gall, O., 2010. Influences des glaciaires-interglacaires sur les ichtyofaunes des eaux douces européennes. Quaternaire 21, 203-214.

Lee, R.B., 1979. What Hunters do for a living, or, How to Make Out on Scarce Resources? In: Lee, R.B., De Vore, I. (Eds.), Man the Hunter, Second edition. Aldine, New York, pp. 30-48 (first edition 1968).

Lernau, H., 1985. Fish remains from Hatoula. In: Lechevalier, M., Ronen, A. (Eds.), Le site Natoufien-Khiamien de Hatoula près de Latroun, Israël. Fouilles 1980-1982. Rapport préliminaire. Cahier du Centre de Recherche Français de Jérusalem. 1. Association Paléorient, Paris, pp. 102.

Lernau, H., Lernau, O., 1991. The fish remains. In: Lechevalier, M., Ronen, A. (Eds.), Le gisement de Hatoula en Judée occidentale, Israël. Mémoires et Travaux du Centre de Recherche Français de Jérusalem. 8. Paris, Association Paléorient, pp. 111-124.

Lubinski, P.M., 1996. Fish heads, fish heads: an experiment on differential bone preservation in a salmonid fish. J. Archaeol. Sci. 23, 175-181.

Morales, A., Rosello, E., 1998. Casual or intentional? Comments on fish skeletal representation from Iberian archaeological settlements. In: Anreiter, P., Bartosiewicz, L., Jerem, E., Meid, W. (Eds.), Man and the Animal World. Studies in Archaeozoology, Archaeology, Anthropology and Palaeolinguistics in Memoriam Sandor Bökönyi. Archeolingua Alapitvany, Budapest, pp. 383-394.

Napierala, H., Van Neer, W., Kandell, A.W., Peters, J., Uerpmann, H.-P., Conard, N.J., 2013. Fish in the desert? The Younger Dryas and its influence on the Paleoenvironment at Baaz Rockshelter, Syria. In: Bar-Yosef, O., Valla, F.R. (Eds.), Natufian Foragers in the Levant. Ann Arbor, International Monographs in Prehistory, International Series. 19. pp. 73-82.

Nicholson, R.A., 1993. An investigation into the effects on fish bone of passage through the human gut: some experiments and comparisons with archaeological material Circaea 10, 38-52.

Nicholson, R.A., 2000. Otter (Lutra lutra L.) spraint: an investigation into possible sources of small fish bones at coastal archaeological sites. In: Huntley, P., Stallibrass, S. (Eds.), Taphonomy and Interpretation. Owbow Books, Oxford, pp. 55-64.

Ombredane, D., Baglinière, J.-L., Berrebi, P., 2011. La Truite commune. In: Keith, P., Persat, H., Feunteun, E., Allardi, J. (Eds.), Les poissons d'eau douce de France. Biotope - Muséum National d'Histoire Naturelle, Paris, pp. 383-403.

Perrot, J., 1960. Excavations at Eynan (Ain Mallaha), preliminary report on the 1959 season. Israel Explor. J. 10 (1), 14-22.

Perrot, J., 1966. Le gisement natoufien de Mallaha (Eynan), Israël. l'Anthropologie 70
(5-6), 437-483.

Perrot, J., 1968. Premiers villages de Syrie et de Palestine. C. R. Académie des Inscriptions et Belles-Lettres. pp. 161-177.

Porcher, J.-P., Baglinière, J.-L., 2011. Le Saumon atlantique. In: Keith, P., Persat, H., Feunteun, E., Allardi, J. (Eds.), Les poissons d'eau douce de France. Biotope - Muséum National d'Histoire Naturelle, Paris, pp. 394-397.

Reimer, P.J., Bard, E., Bayliss, A., Beck, J.W., Blackwell, P.G., Ramsey, C.B., Buck, C.E., Cheng, H., Edwards, R.L., Friedrich, M., Grootes, P.M., Guilderson, T.P., Haflidason, H., Hajdas, I., Hatté, C., Heaton, T.J., Hoffmann, D.L., Hogg, A.G., Hughen, K.A., Kaiser, K.F., Kromer, B., Manning, S.W., Niu, M., Reimer, R.W., Richards, D.A., Scott, E.M., Southon, J.R., Staff, R.A., Turney, C.S.M., van der Plicht, J., 2013. IntCal13 and Marine13 radiocarbon age calibration curves 0-50,000 years cal BP. Radiocarbon 55, 1869-1887.

Sanford, C.P.J., 2000. Salmonoid Fish Osteology and Phylogeny (Teleostei: Salmonoidei). A.R.G. Gantner Verlag KG, Rugell, Liechtenstein.

Sušnik, S., Schöffmann, J., Snoj, A., 2004. Phylogenetic position of Salmo (Platysalmo) platycephalus Behnke 1968 from south-central Turkey, evidenced by genetic data. J. Fish Biol. 64, 947-960.

Sušnik, S., Knizhin, I., Snoj, A., Weiss, S., 2006. Genetic and morphological characterization of a Lake Ohrid endemic, Salmo (Acantholingua) ohridanus with a comparison to sympatric Salmo trutta. J. Fish Biol. 68, 2-23.

Tchernov, E., 1997. Are late Pleistocene environmental factors, faunal changes and cultural transformations causally connected? The case of the Southern Levant Paléorient 23 (2), 209-228.

Turan, D., Kottelat, M., Bektas, Y., 2011. Salmo tigridis, a new species of trout from the Tigris River, Turkey (Teleostei: Salmonidae). Zootaxa 2993, 23-33.

Valla, F.R., Bar-Yosef, O., Smith, P., Tchernov, E., Desse, J., 1986. Un nouveau sondage sur la terrasse d'El-Ouad, Israël. Paléorient 12 (1), 21-38.

Valla, F.R., Khalaily, H., Samuelian, N., Bocquentin, F., Delage, C., Valentin, B., Plisson, H., Rabinovich, R., Belfer-Cohen, A., 1998. Le Natoufien final et les nouvelles fouilles à Mallaha (Eynan), Israel (1996-1997). J. Israel Prehist. Soc. Mitekufat Haeven 28, $105-176$.

Valla, F.R., Khalaily, H., Valladas, H., Tisnerat-Laborde, N., Samuelian, N.E., Bocquentin, F., Rabinovich, R., Bridault, A., Simmons, T., Le Dosseur, G., Rosen, A.M., Dubreuil, L., Bar-Yosef Mayer, D., Belfer-Cohen, A., 2004. Les fouilles de Ain Mallaha en 2000 et 2001: 3ème rapport préliminaire. J. Israel Prehist. Soc. Mitekufat Haeven 34 49-244.

Valla, F.R., Khalaily, H., Valladas, H., Kaltnecker, E., Bocquentin, F., Cabellos, T., BarYosef Mayer, D., Le Dosseur, G., Regev, L., Chu, V., Weiner, S., Boaretto, E., Samuelian, N., Valentin, B., Delerue, S., Poupeau, G., Bridault, A., Rabinovich, R., Simmons, T., Zohar, I., Ashkenazi, S., Delgado Huertas, A., Spiro, B., Mienis, H.K. Rosen, A.M., Porat, N., Belfer-Cohen, A., 2007. Les fouilles de Ain Mallaha (Eynan) de 2003 à 2005: quatrième rapport préliminaire. J. Israel Prehist. Soc. Mitekufat Haeven 37, 135-379.

Valla, F.R., Khalaily, H., Samuelian, N., Bridault, A., Rabinovich, R., Simmons, T., Le Dosseur, G., Ashkenazi, S., 2013. The final Natufian structure 215-228 at Mallaha (Eynan), Israel: an attempt at spatial analysis. In: Bar-Yosef, O., Valla, F.R. (Eds.), Natufian Foragers in the Levant. Ann Arbor. International Monographs in Prehistory, International series. 19. pp. 145-171.

Valla, F.R., Khalaily, H., Samuelian, N., Bocquentin, F., Bridault, A., Rabinovich, R., 2017 Eynan (Ain Mallaha). In: Enzel, Y., Bar-Yosef, O. (Eds.), Quaternary of the Levant. Cambridge University Press, Cambridge, pp. 295-301.

Van Neer, W., Zohar, I., Lernau, H., 2005. The emergence of fishing communities in the eastern Mediterranean region: a survey of evidence from pre- and protohistoric periods. Paléorient 31, 131-157.

Weissbrod, L., Marshall, F.B., Valla, F.R., Khalaily, H., Bar-Oz, G., Auffray, J.-C., Vigne, J.D., Cucchi, T., 2017. Origins of house mice in ecological niches created by settled hunter-gatherers in the Levant 15.000 years ago. PNAS 114 (16), 4099-4104.

Wheeler, A., Jones, A.K.J., 2009. Fishes. Cambridge University Press, Cambridge.

Willis, L.M., Eren, M.I., Rick, T.C., 2008. Does butchering fish leave cut marks? J. Archaeol. Sci. 35, 1438-1444.

Zohar, I., Goren, M., Goren-Inbar, N., 2014. Fish and ancient lakes in the Dead Sea Rift: the use of fish remains to reconstruct the ichthyofauna of paleo-lake Hula. Palaeogeogr. Palaeoclimatol. Palaeoecol. 405, 28-41. 